\title{
DE GESCHIEDENIS VAN EEN BOEK \\ DOOR
}

FRED. OUDSCHANS DENTZ

In 1785 verscheen er in de Nederlandsche Courant van 7 December, No. 146, een advertentie van den boekverkooper Cornelis van der Aa, te Haarlem, van den volgenden inhoud:

„De boekverkooper van der Aa te Haarlem heeft ge„drukt en verzend thans alom: ....

„Het publiek verwachte eerlang eene verhandeling over „den landbouw in Surinamen, een interessant stuk voor elk die eenig belang heeft in ,den bloei deezer volkplan"ting."

Het hier bedoelde boekwerk zou aanleiding worden tot een wrijving tusschen twee personen die jaren met elkaar in Suriname goede vrienden waren geweest, nl. Mr. Floris Visscher Heshuysen en Anthony Blom.

In de eerste plaats eenige bijzonderheden over de hoofdpersonen in deze geschiedenis.

F. V. Heshuysen, oud Schepen van de stad Haarlem, werd in 1739 geboren. Hij vertrok naar Suriname, waar hij in ambtelijken dienst trad en opklom tot „Controlleur Generaal over de Edele Directie, soldijen en magazijnen en Departementen", lid van de Kleine en Conferentie Raad van Justitie, Weesmeester en Commissaris der Nieuwe wees- en onbeheerde Boedel-Kamer, mitsgaders der Nieuwe Curateele Kaamer om ten slotte BoekhouderGeneraal te worden.

De Gouverneur-Generaal Sir Charles Green schreef ${ }^{\mathbf{1}}$ ) over hem aan Earl Cambden „,(dat) Heshuysen (was) een

1) 2 October 1804 . 
man grijs geworden in den dienst der Kolonie, goed met de finantieele en andere aangelegenheden bekend, bekwaam in het fransch en redelijk wel bedreven in het Engelsch".

Toen dan ook in 1805 een zekere Mr. Henhuis (wonderlijke woordspeling) met aanbevelingsbrieven van de Regeering in Engeland naar Suriname kwam om tot Boekhouder-Generaal te worden benoemd, aarzelde de Gouverneur niet dit ambt, waarmede Heshuysen reeds provisioneel was belast, definitief aan hem toe te vertrouwen. Den 16en Juli 1805 werd hij als zoodanig beëedigd.

Om kennis van den geldelijken toestand, enz. te bekomen vervoegde zich de Gouverneur Sir. Ch. Green tot den Raad-Boekhouder-Generaal Heshuysen, die daarop verscheidene belangrijke memoriën ${ }^{1}$ ) in de fransche taal een vrij goed overzicht gaf van den financieelen toestand en daarbij de geschiedenis van de achtereenvolgende ingevoerde belastingen, van den oorsprong van het kaartengeld, der obligatiën mededeelde. Evenzoo waren de memoriën van Heshuysen over den landbouw en handel, over de Indianen, den strijd met de wegloopers, den toenmaligen toestand der bevredigde Boschnegers, die nog in vijandschap met het Gouvernement leefden, hoogst belangrijk. Door deze memoriën ${ }^{2}$ ) werd het Britsche Gouvernement in staat gesteld om den toestand bij de overgave der Kolonie te leeren kennen.

Heshuysen brak op 15 April 1806 een been, lezen wij in het Journaal van den Gouverneur. Het volgend jaar staat daarin aangeteekend op 6 Augustus 1807 (dat) ,hij deeser waereld overleed in den ouderdom van 68 jaaren".

Met Heshuysen was een man van groote gaven heengegaan. Niet alleen de Finantiën, ook handel en landbouw hadden zijn aandacht. Hij was eigenaar van plantage „Helena Christina" en Administrateur van een 12-tal plantages in Suriname.

1) Diverses Mémoires de Heshuysen.

2) Mémoire sur les appointements tels que se payent actuellement. 9 Aout 1804. Mémoire sur l'état des Finances Coloniales faite par Heshuysen. 16 Juillet 1805 . 
Een onafgebroken omgang met Anthony Blom gedurende den tijd van twee jaren, welke hij meerendeels doorbracht op de plantage, waarin hij deelgenoot was en welke aan zijn zorgen was toevertrouwd, zijn hem van „onwaardeerbaar nut geweest". Het had zijn aandacht en die van Blom getrokken dat het werk van Fermin ${ }^{1}$ ) in vele opzichten niet juist was, waarop Blom het plan opvatte een schets van den Surinaamschen landbouw te maken en die aan Heshuysen te overhandigen, maar „,vermits ik een „slechte pennist ben, hoewel daartoe veele stoffe is, zal ik „,wel twee en mogelijk drie maanden werk hebben.... „dat gereed zijnde twijfele geenszins of UEd. zult daar ,grooten smaak in vinden en ook een zeer nuttig gebruik „van konnen maken”, schrijft Blom aan Heshuysen.

Anthony Blom was van zijn jeugd af in Europa in het hoveniers- of tuinmanswerk geweest. Hij besloot naar Suriname te gaan, waar hij 24 Januari 1766 voet aan wal zette. Ruim 20 jaren woonde hij op een plantage, 4 jaren als „minder dienaar, namelijk als tuinier en officier” ${ }^{2}$ ), de volgende jaren als Directeur of Bestuurder. Ongetwijfeld was hij een kundig man in zijn vak. In de Surinaamsche Almanak van 1793 en van 1798 zie ik dat hij is Administrateur van 7 plantages, waaronder van de „Societeitsgrond, waarvan de heeren Directeuren en Regeerders der Colonie eigenaars zijn" en Directeur van de plantage „Weltevreden” aan de Suriname-rivier, eveneens toebehoorende aan genoemde Directeuren.

De verschijning van de „Verhandeling over den landbouw, in de Colonie Suriname, volgens eene negentienjaarige ondervinding zamengesteld, door Anthony Blom: in orde gebragt; en met de noodige ophelderingen en bewijsredenen voorzien, door, Floris Visscher Heshuysen, oud schepen der stad Haarlem, mitsgaders oud Raad van Justitie, der Colonie Suriname", zooals de wijdloopige titel luidt, en in 1786 verschenen, ontlokte aan Blom de ont-

\footnotetext{
1) Philip Fermin, Beschryving van de Kolonie Suriname, Harlingen, 1770, 2 dln.

2) d. i. blankofficier-opzichter, afgeleid van blanke overseer.
} 
boezeming, welke men in onderstaande advertentie ${ }^{\mathbf{1}}$ ) ziet aangeteekend:

„Anthonie Blom, met verwondering in de Amsterdamsche Cou„rant van den $3 \mathrm{e}$ January 1786 geleezen hebbende, dat by den „Boekverkooper Cornelis van der Aa tot Haarlem, was gedrukt en „,wierd uitgegeven zeker werk, geintituleerd: Verhandeling over „den landbouw in de Colonie Surinamen, volgens een I9-jaarige on„dervinding, samengesteld door Anthonie Blom, in order gebragt "met de noodige Ophelderingen en Bewysredenen voorzien; door „Floris Visscher Heshuyzen, Oud Schepen der stad Haarlem, mits„gaders Oud Raad van Justitie der Colonie Suriname, vind zig als „nu verpligt te declareeren, dat hij wel is waar de schrijver is van „de Surinaamse Landbouw, dan geenzins zo en in dier voege als „dezelven door den heer Floris Visscher Heshuyzen uitgegeeven, „thans het ligt ziet; hebbende hy Anthonie Blom ook nimmer de „Heer Heshuyzen verzogt, veel minder geauthoriseert dit zijn „werk in order te brengen, met de noodige Ophelderingen en Be„wysredenen te voorzien, maar wel ter Contrarie by zyn vertrek „,uit deeze Colonie zyn Ed ter Lecture overgegeeven, met verzoek „hetzelve van de schryf- en Taalfouten te willen zuiveren, en by „behouden aankomst als dan voor rekening van hem Anthonie „Blom te willen doen drukken.

„De door den Heer Heshuyzen in order brenging en byvoeging „van Ophelderingen en Bewysredenen zyn dan oorzaak dat den „schryver van 't zelfde Werk zig deeze verminkte en op een si„nistre wyze gedaane Uitgaave niet kan nogte vermag aan te "trekken; als hebbende deeze byvoeging des schryvers waare in„tentie en goede inzigten niet alleen verbasterd, maar deeze Land„bouwbeschryving (hetgeen alleen het eenige en waare dagwerk "van den schryver is geweest) hier en daar door Politique Staat„kundige en Financieele Remarques, eene heel andere gedaante „gegeeven omme welke redenen hy dan A. Blom by deezen adver„teerd, dat door hem ten spoedigsten een waaren en onvervalsch"ten Landbouw Beschryving ter Drukpers zal gebragt, en aan ",t Publieq aangeboden worden, met vriendelyk verzoek aan een „,ieder, zyn oordeel over dit Werk tot dien tyd op te schorten, als "wanneer men het Basterd, dat thans het licht ziet, van het echte „ligtelyk zal kunnen onderscheiden.

Surinamen, den 25 July 1786"

De boekverkooper Van der Aa gaat voort met adverteeren en kiest blijkbaar partij voor Heshuysen in de volgende bekendmaking:

1) Nederlandsche Courant. Ao. 1786, no. 26, Vrijdag 20 October, uitgegeven bij Jan Verlem in de Warmoesstraat, Amsterdam. 
„De boekverkooper van der $A a$ debiteert met goed succes, de by „hem onlangs uitgegeevene: Verhandeling over de landbouw in de „colonie Surinamen, opgesteld door A. Blom, en met de noodige "Ophelderingen verrykt, uitgegeeven door Mr. F. V. Heshuyzen, „à f 2:16. Schoon de advertentie van A. Blom in sommige couran„,ten gemelde Boekverkooper in 't geheel niet raakt, (als alleen „betreklyk zynde tot de manier waar op het voorschreeven werk "op speciaal verzoek van A. Blom, door den Heer Heshuyzen ter „Perse bezorgd is) waarom hy dit verschil tusschen die beiden in „zyn geheel laat, zo agt hy egter nut, het Publiek te verzoeken, de "Voorrede van de Uitgevers vóór dat Werk geplaatst, te leezen, ",als wanneer elk onpartydige zien zal; dat de Uitgaave, met voor„kennis niet alleen, maar op verzoek van den schrijver geschied. In",tusschen oordeelen deskundigen, dat de Politieke en Financieele „Remarques (waarop men het wel het meest schijnt geladen te „hebben) van de allergrootste nuttigheid zijn voor alle Ingezeetenen ",deeser Republiek, die hunne schatten, zoo ruimschoots tot behoud „van de Colonie Surinamen hebben opgeschooten, vermits elk door „de bereekeningen van de Lasten en Inkomsten eener Plantagie, "die in dat werk ten getale van elf voorkomen, in staat gesteld „,is over de wezentlijke waardij dier Plantagiën te oordeelen, en "waar door de onbetrouwbaarheid van veele Fondsen aan het "licht komt. Of nu deeze Remarques de waardij des werks al of ",niet vermeerderd, zij het Publiek gerustlijk aanbevolen. Men zie ",het nut deezes werks verder in de gunstige beoordeeling van de Uit"gevers der Nederlandsche Bibliotheek en Vaderl. Letteroefeningen. „heden uitgegeeven" ${ }^{1}$ ).

De beoordeelingen over het verschenen werk waren gunstig. Ik haal hier aan een stuk uit de Nieuwe Algemeene Nederlandsche Letteroefeningen en de Nieuwe Nederlandsche Bibliotheek:

Nieuwe algemeene Nederlandsche Letter-Oefeningen ${ }^{2}$ ):

„Schoon' er veele schrijvers ter bevordering van de kennis der „volkplanting Suriname zich de moeite gegeeven hebben, van „hetgeen hen daarvan bewust was, aan hunne landgenooten door "den druk bekend te maaken, is echter dat gedeelte, waarbij onze „Landgenooten het meest belang hebben, de Landbouw namelijk, „door geen een schrijver, die daarvan door ondervinding eene „genoegzaame kennis verkregen had, opzettelijk en in alle zijne „takken en deelen verhandeld; want het geen de Heer Fermin, ,in zijne zogenaamde beschrijving van Suriname, omtrent den

1) Nederlandsche Courant van Maandag 6 November 1786, no. 133.

2) 1e deel, eerste stuk, te Amsterdam, bij A. van der Have en G.J Ynkema, 1786, blz. 458/465. 
„Landbouw heeft aangetekend, is geheel verkeerd, en meest al „overgenomen uit Pater Labat, zodat zelfs de Plaaten van de Sui„kermolens, zo wel van een waterwerk als van de beestenwerk, „trek voor trek, naar die van Labat gecopieerd zijn, en, zo de „Heer Fermin, noch iemand anders, gelijk de uitgeever van het „hier aangekondigde werk verzekert, in de geheele Colonie eene „Plantagie kan aanwijzen, alwaar zulk een Zuikermolen, hetzij „van waterwerk of beestenwerk te vinden is. Uit dien hoofde „moet een verhandeling, zo uitvoerig als deeze, welke de vrucht „is van een negentienjaarige ondervinding in den Landbouw dee„zer Colonie, door den schrijver eerst als Tuinman, vervolgens „als Blanken officier en daarna als Directeur verkreegen van on„gemeen veel nut zijn, niet alleen voor veele eigenaars van Plan„tagiën, die nooit in Surinamen geweest zijn, maar ook voor de "geldschieters op Plantagiën, die dezelven tot voorkoming van „grootere schade hebben overgenomen, alsmede voor de Heeren "Commissarissen en Directeuren van Geldleeningen, onder wel„ker beheering thands die Plantagiën staan, doch welke Heeren „gemeenlijk van de gesteldheid der Colonie, die ze nooit gezien „hebben, geheel onkundig zijn. Dan het nut van zodanig eene „verhandeling wordt in die gevallen nog meer uitgebreid, wan„neer men, behalven de aanwijzing van het geen in het planten „en bewerken van de voortbrengsels, van dit gewest, in acht te „neemen is, ook de gronden aantoont, op welke men een Planta"gie beheeren moet, en hetgeen men verder omtrent dezelven in „het oog moet houden en zulks met bewijzen staaven kan, die ge„schikt zijn naar den aart der zaaken, en hiertoe heeft de Heer „uitgeever veel toegebragt, die de verhandeling van den Heer „Blom in eene geschikte orde gebragt, met nadere bewijzen opge„helderd, en met veele bijvoegselen vermeerderd heeft."

Daarna volgen eene bespreking en eenige aanhalingen uit het boek, eindigende met de woorden: „dan ons bestek laat niet toe, „hierover breeder uit te weiden, en wij zijn dus verplicht, den „Leezer, die des wegens eenig nader bericht verlangt, het werk „zelve aan te prijzen".

\section{Nieuwe Nederl. Bibliotheek ${ }^{1}$ ) :}

„Door een gemeenschappelijken en aan elkander behulpzamen „arbeid, welke de Heeren Blom en Heshuijzen tot het opstellen „van deeze Verhandelinge besteed hebben, ziet men hier een werk „,te voorschijn komen, welks leezing en gebruik wij zeer aanraa„den aan allen die belang stellen of verkiezen te stellen in den „Surinaamsche Landbouw.

1) 6e deel, 1e stuk te Rotterdam en te Amsterdam bij Martinus de Bruyn in de Warmoesstraat, het 6e huis van de Vischsteeg, Noordzijde, 1786, blz. 416 . 
„Toe de Heer Heshuyzen, in het jaar 1784, voornam, eene reize „uit Suriname naar het Vaderland te doen, gaf hij van dat voor„neemen kennis aan den Heer Blom, en verzogt hem eenige on„derrigting omtrent hetgeen men in acht moest neemen, wanneer „men een nieuwe Plantagie wilde aanleggen, vermits hetgeen de "Heer Fermin in zijne zoogenaamde Beschrijvinge van Surinamen „zegt, geheel verkeerd is; en daar het somwijlen zou kunnen ge„,beuren, dat lieden die in de Colonie niet geweest zijn, zich daarop „zouden beroepen, wilde de Heer H. gaarne in staat zijn, niet „alleen om de misslagen van den Heer F. te kunnen aantoonen, „maar ook om de manier aan te wijzen, waar op men zulken nieu„wen aanleg moet beginnen en voortzetten.

„De Heer H. had wel, toen hij in Surinamen was, zijn aandagt „bepaald op het geen tot den Landbouw betrekking had, en om „tot kennis daar van te geraaken, was hem van groot nut geweest „een bijna onafgebrooken omgang met den Heer B. geduurende "den tijd van twee jaren, welke zijn Wel.Ed. meerendeels had „doorgebragt op de Plantagie, waarvan hij deelgenoot en be„stierder was; maar het was hem des niet tegenstaande onmo"gelijk om bij ondervinding te zien, hoedanig men eene Plan„tagie nieuw moet aanleggen, vermits, 'er geduurende zijn „verblijf in Surinamen, zijnes weetens, geen nieuwe Plantagie „,aangelegd is.

„Hierom raad Zijn Wel. Ed. ten einde daarvan eene gewenschte „kennis te verkrijgen, het gemelde werk van F. aan den Heer B., „met verzoek om hem zoodanige onderrigting te geeven, waar "door hij in staat zou zijn, zijne landgenooten, die dit mogten „begeeren, te kunnen voldoen.

„De Heer B. dat werk door geleezen hebbende, antwoordde, „dat dat zelve was kinderagtig, onwaar, en nog meest gecopieerd „uit Pater Labat, en beloofde teffens eene breedvoerige schets „van den Surinaamschen Landbouw te zullen beschrijven, en aan „den Heer H. dan over te geeven, en daarvan een nuttig gebruik „te maaken.

„Aan die belofte werd voldaan, dat de Heer H. deze Verhan„deling ontving welke Zijn Wel. Ed. vervolgens in geschikte orde „gebragt, en ter drukperse, ten nutte der Vaderlanderen heeft „bezorgd.

„Den zaakelijken inhoud en hoofdbedoeling van dezelve „kunnen wij onzen leezer niet beter opgeeven, dan met de eigen „woorden van den Heer $\mathrm{H}$. in het voorbericht, alswaar bijschrift.

„Dit achten wij genoeg om een Werk van deezen aart onder de „aandacht van onze landgenooten te brengen, en de leeslust der„zulken gaande te maken, wier begeerte of belang zich tot eene "geregelde kennis van Surinamen en deszelfs Landbouw uit„strekt. - De prijs is $f 2.16$." 
Heshuysen keerde in 1786 van zijn reis naar Nederland in de Kolonie terug, waar hij op 23 November aankwam en kennis nam van de waarschuwing van zijn vriend Blom, in de Nederlandsche en Surinaamsche krânten geplaatst.

In de Surinaamsche Nieuwsvertelder van 18 Januari $\left.1787^{1}\right)$ plaatste hij daarop het volgende verweer:

„De ondergetekende op den 20 September laatstleden met het „schip gevoert door Capit. Reyndert Luytjes uit Texel vertrokken „op den 23 November in de Colonie Suriname geretourneert „zijnde, heeft met veel bevreemding gezien, dat Anthonie Blom „heeft kunnen goedvinden in de Nederlandsche Courant van den "20 October als mede in het Weekblad genaamt De Surinaamsche „Nieuwsvertelder van den 3 Augustus no. 61 en dus na zijn ver„trek uijt Holland en voor zijne aankomst in Suriname, (derhalve „op Tijdstippen waarin het de Ondertekende onmogelijk was om „zig dadelijk te kunnen zuyveren van het geene waarmede hij door „Anthonie Blom betigt wierd) te plaatzen zeekere bekentmaking ",wegens de verhandeling over den landbouw van Suriname door "Anthonie Blom geschreven en door de ondergeteekende in „ordre gebragt en met de nodige Ophelderingen en Bewijsredenen „,voorzien bij den Boekverkooper C. van der Aa tot Haarlem ge„drukt; welke verhandeling Anthonie Blom om reden van deze ",in ordrebrenging en Bijvoeging van Ophelderingen, verklaart „,te zijn eene verminkte en op eene sinistere wijze gedaane Uytga„,ven welke hy zig (zo hy zegt) om deze Reeden niet kan aan„,trekken met bijvoeging van verscheyde soortgelijke onwelle„,vende Uijtdrukkingen meer; vind de ondergetekende zig ver",pligt bij deze te verklaaren; dat hij noit eenig Manuscript of „Werk van Anthonie Blom met zig naar den Vaderlande heeft "genomen, hebbende hij hetzelve eygenhandig overgeschreven ,en in die orde gebragt waarin het naderhand door hem is in het „Ligt gegeven en onder 't schrijven stuksgewijs aan Anthonie „Blom ter Examen toegezonden; dat hij daarin geene Verande„,ringen heeft gemaakt als die van welke hij in de Voorreeden ge„wag gemaakt heeft; dat hij het Manuscript met de Hand van „Anthonie Blom geschreven, aan hem terug heeft gegeven, voor „,zijn vertrek uyt deze Colonie dat hij nooijt last gehad heeft om „dit of eenig ander werk van Anthonie Blom voor zijne Reeke„,ning waardoor men in de Boekhandel verstaat op zijne Kosten, „Baten en Schaden te laten drukken, dat hij ondergeschreven na „zijn Vertrek uyt de Colonie nog verscheide Brieven van Antho„,nie Blom over deeze Verhandeling heeft ontfangen als in dato „11 Maart 6, 16 en 28 April en 13 Augusti 1785, alle welke brie-

1) 18 Januari 1787, No. 85, blz. 4 . 
„ven nog voorhanden zijn, maar dat het schijnt of Anthonie „Blom ofte wel zijn Raadsman zedert van gedagten ofte van in„zigten verandert is, dat het een en ander blijkt uijt zijne Brief „van den 20 December 1785, waarin hij aan de Ondergetekende „woordelijk het volgende heeft gemeld.

„Nu koomende tot den Landbouw, dient dat ik van tijd tot „tijd meer en meer ontwaar word de menigvuldige groote Fouten "die er in zijn ontstaan door die Uwe Ed. al te schielijk Vertrek, „waardoor ik geen tijd genoeg had om alles behoorlijk na te den"ken, en Uwe Ed. daarbij (in dit woord is waarschijnlijk eene "schrijffoute)" 't overschrijven verscheiden Dingen in geplaats "heb, die tot den Landbouw geen betrekking hebben, ik wil hope "Uwe Ed. het zelve nog niet in Druk zal hebben doen geven, om "dat ik het nu in eene heel andere beter Smaak en van zijn Fouten "gesuyferd heb overgeschreven, en denkelijk hier zal laten druk„ken, egter moet ik vooraf weten of Uwe Ed. 't zelve reeds „hebt "doen drukken, zoo ja om mijn dan in de Voorreden daarna te „kunnen reguleeren" en vertrouwde Ondergeschreven hiermede "de Aantijgingen van Anthonie Blom voor onpartijdig Publik "volledig te hebben wederlegt; egter indien Anthonie Blom ofte „zijn Raadsman mogte goedvinden, direct of indirect iets van "het in deze Advertentie geposeerde te willen ontkennen, ver"bind zig de Ondergeteekende in dien gevallen, het in de boven"gemelde Vijf Brieven en anderen nog, betrekkelijk tot deeze "Uytgaave geschreven, door den Druk aan den Dag te zullen „leggen en extracten authenticq ter secretary deezer colonie te „zullen seponeeren.

Paramaribo, den 17 Januarij, 1787. F. v. Heshuysen."

Daarna lees ik nog twee advertenties, een van Blom op 15 Februari 1787 en een van Heshuysen van 8 Maart van dat jaar, van den volgenden inhoud:

1. Van Blom ${ }^{1}$ ).

„Voorts ten Reguarde der Advertentie door den Ed. Achtbaare „Heer F. v. Heshuysen in 't Weekblad de Nieuwsvertelder de „dato 8 Junij 1786 sub No. 56 gesteld, Adverteerd hij A. Blom als „dat hij zig als nog refereerd aan zijne gedaane Advertentie zoo „hier als in de Vaderlandsche Couranten met Renvoy aan den "onpartijdigen Leezer van de nadere uytgiften van dit werk, „waar bij hij uyt het Werk zelve of bij Voorreeden ofte wel al ter „Drukperse gebragt zijnde, bij Suppletie nader de waare en ge"grondheyd van zijn reeds gedaane Advertentie zal ontwaar ",worden."

1) De Surinaamsche Nieuwsvertelder, 15 Februari 1786, no. 89, blz. 6 . 
2. Van Heshuysen ${ }^{1}$.

„F. v. Heshuyzen, als nog persisterende bij zijn gedaane Ad„vertissement van den 18 January dezer Jaars, verklaart niet te „min te zullen afwagten de nadere Uytgave van het werk van "Anthonius Blom, omme uyt het Werk zelve, de Voorrede, of "Supletie te zien, waarop de zogenaamde gegrondheid zijner Ad„vertissement van den 3 Augustus alhier den 20 October in den „Vaderlande mag rusten, alvorens het gene in de Vijff brieven „van Anthonie Blom en nog andere waarvan in de boven ge„melde Advertentie van den 18 January door den Druk aan den „Dag te zullen leggen.

„blijvende des onvermindert zijne belofte in zijn geheel."

Hier eindigt het debat.

Blom doet zijn belofte gestand en geeft in 1787 uit te Amsterdam bij J. W. Smit, boek- en konstverkooper op de Bierkade een ,Verhandeling van den Landbouw, in de Colonie Suriname", een werk van 355 bladzijden in 24 hoofdstukken, opgedragen aan „Hunnen Wel Edele Groot Achtbaarheden den Heeren Dierecteuren en Regeerders der Colonie Suriname".

Het eerste werk, dat van Blom en Heshuysen groot 448 bladzijden in 20 hoofdstukken was opgedragen „Aan den WelEdelen Groot Achtbaaren Heere den Heer Hendrik G. Hooft Danielz., President Burgemeester der stad Amsterdam, enz. enz. enz."

Heshuysen achtte het raadzaam, met het oog op den achteruitgang der plantages uitvoerige becijferingen te geven. Hij overwoog n.l. ,dat alle beurzen gesloten wier„den is de ellende van alle deeze planters algemeen ge„worden; de meesten van hun zijn geruïneert zo wel als „hun borgen, en hun plantagien zijn of bij executie ver„kogt, of voor de fondsen overgenomen, of meer en meer

1) Ibidem, 8 Maart 1787, no. 92, blz. 7 .

De familie Heshuysen te Haarlem was ook op andere wijze in WestIndië geïnteresseerd. In de geldleeningen aan de planters in de koloniën Demerara en Essequibo-negotatien ontstaan door toedoen van den Middelburgschen burgermeester Kornelis van den Helm Boddaert, werd in 1772 medewerking verkregen voor de negotiatie van een millioen gulden, van het Haarlemsche huis Adolf Jan Heshuysen \& Co, dat ook in Amsterdam een kantoor had, en eigenaar was van de koffie- en katoenplantage „Welbedagt” aan de Surinamerivier en van de suikerplantage „Nahamoe” aan dezelfde rivier. 
„ten achteren gegaan”. Zoo vinden wij de volgende belangrijke gegevens:

1. Een calculatie of berekening van een suikerplantagie met een waterwerk, waarop jaarlijks 500 vaten suiker à 1000 ponden ieder, worden gemaakt.

2. Een calculatie of berekening over een suikerplantagie, met een beestenwerk, waarop jaarlijks 300 vaten suiker à $1000 \mathrm{lb}$ ieder gemaakt wordt.

3. Een calculatie of berekening over een coffy-plantagie op welken jaarlijks $195000 \mathrm{lb}$ coffy wordt gemaakt.

4. Alsvoren met $95000 \mathrm{lb}$ coffy.

5. Eene berekening van een cacaoplantagie waarop jaarlijks $360000 \mathrm{lb}$ cacao gemaakt word.

6. Een berekening over een catoen-plantagie waarop jaarlijks $76660 \mathrm{lb}$ catoen word gemaakt.

Het boek eindigt met ,een uitlegging van de kunstwoorden en anderen welke in deeze verhandeling voorkomen", een onmisbare handleiding. Blom was beknopter. Hij geeft:

1. Een calculatie der kosten van aanleg alsmede de jaarlijksche onkosten en onderhoud eener zuiker Plantagie met een watermolen en dubbeld ketelwerk, met 232 koppen slaaven, groot 1636 akkers Land, benevens de daarvan komende revenuen, na aftrek der intresten.

2. Calculatie over de onkosten van aanleg, als meede de jaarlijksche onkosten aan intressen, onderhoud en revenu van een koffy Plantagie met 252 koppen Slaaven en 1000 Akkers Land.

3. Calculatie over de kosten van aanleg, alsmede de jaarlijksche onkosten aan intressen en onderhoud en revenue van een cacao Plantagie met 210 koppen slaaven, en 1000 Akkers Land.

4. Calculatie over de kosten van aanleg, alsmede de jaarlijksche intressen onderhoud en revenu, van eene Katoen Plantagie met 240 koppen Slaaven en 1000 Akkers Land.

De uitgebreide verklaring van vreemde en onbekende woorden geeft hij niet.

Mijns inziens wint de eerste uitgave, nl. die waaraan Heshuysen had medegewerkt, het van de uitgave van Blom alleen.

Ten slotte wijzen wij tot besluit nog op de voorrede van Heshuysen, waar deze zegt, in welk hoofdstuk wijziging 
te hebben aangebracht ,,vermits ik mijnen naam aan het „hoofd deezer verhandeling laatende gebruiken, den lee„zer hieruit over het geheel genomen, zoude konnen aflei"den, wat het werk van den schrijver, en wat het mijne is, „en men mij niet zou verdenken, dat ik, gelijk de Raaf in "de fabel, wilde pronken met de veederen van de Paauw: „veelligt zou ik mijnen naam in het geheel hebben achter"gelaaten".

Nog rest hier mede te deelen dat Blom ook de schrijver was van „De Surinaamsche landman, of verhandeling over verscheiden belangrijke onderwerpen den Surinaamschen landbouw betreffende," Paramaribo, 1801 en 1805. 